\title{
Variability of Morphological Traits of European Beech (Fagus sylvatica L.) Seedlings in Serbia
}

\author{
Vladan Popović ${ }^{1, *}$, Aleksandar Lučić ${ }^{1}$, Ljubinko Rakonjac ${ }^{1}$
}

(1) Institute of Forestry, Kneza Viseslava 3, RS-11000 Belgrade, Serbia

Citation: Popović V, Lučić A, Rakonjac Lj, 2021. Variability of Morphological Traits of European Beech (Fagus sylvatica L.) Seedlings in Serbia. South-east Eur for 12(1): 83-89. https://doi.org/10.15177/ seefor.21-06.

Received: 29 Jan 2021; Revised: 4 Apr 2021, 18 Apr 2021; Accepted: 26 Apr 2021; Published online: 5 May 2021

\begin{abstract}
The results of interpopulation variability of morphometric parameters of European beech (Fagus sylvatica L.) seedlings originating from eight populations from the part of natural distribution area in Serbia are presented in this paper. The studied populations of Dubašnica, Jastrebac, Boranja, Fruška Gora, Mali Pek, Goč, Beljanica, and Javor have various ecological and vegetational characteristics. The results of this paper refer to root collar diameter and height of seedlings at the age of $1+0$ and $2+0$. Analysis of variance showed a statistically significant difference between the populations in terms of the studied morphological traits of seedlings ( $p<0.01 ; \alpha=0.05$ ). Geographical differentiation of the studied populations has not been determined by applying cluster analysis, but the populations are grouped randomly and they indicate the ecotypic nature of beech genetic variation. The results of this research may serve in beech breeding and the available gene pool conservation. Based on the obtained results it can be recommended that in terms of transfer and use of the beech forest reproductive material greater attention should be paid to the ecological conditions of the parent stands and habitats where afforestation has been performed.
\end{abstract}

Keywords: European beech; seedlings; variability; population

\section{INTRODUCTION}

European beech (Fagus sylvatica L.) is the most widespread tree species in Europe and also one of the most ecologically and economically important species. Wide ecological amplitude and growth on elevations from $50 \mathrm{~m}$ to over $2000 \mathrm{~m}$ indicate great adaptability of the species and existence of a significant genetic variability. The research of beech genetic variability started by establishing the first provenance test in Germany in 1877 and afterward in other European countries (Vidaković and Krstinić 1985, Kajba 2003). The knowledge of certain morphological, physiological and commercial traits of various beech provenances is very significant for beech breeding, and the selection and recognition of seed stands (Gračan 2003). The conducted research of genetic structure of various beech populations in the area of south-eastern Europe had shown significant genetic variability with dominant ecotypic nature of differentiation (Paule 1995, Gömöry et al. 1999,
Hazler et al. 1997, Gömöry et al. 2007, Šijačić-Nikolić et al. 2007, Ivanković et al. 2011) as well as that the postglacial recolonization started from different refugia (Brus 2010).

The research of genetic diversity especially in some adaptive traits (growth, survival, and phenology) is very important in the context of global climate change. This is particularly significant for populations in the southern parts of the beech distribution area due to a potentially higher risk of warming in this part of Europe (Ivanković et al. 2011). The parent material should possess as high as possible genetic variability because it is crucial for successful manifestation of adaptive traits (Šijačić-Nikolić et al. 2006). The growth and development of beech seedlings are conditioned by photoperiod, heat quantity, and soil and air humidity (Pšidová et al. 2015). Having in mind that these climate factors are not evenly distributed throughout the species distribution area, one can assume that natural selection of different directions and intensities affects the beech population in dependance on climate factors (Màtyàs et al. 2009). 
The objective of this research is to acquire preliminary knowledge of the genetic variability of the studied beech populations based on the quantitative seedling traits in the nursery test.

\section{MATERIAL AND METHOD}

The eight beech populations from the species distribution area in Serbia were selected for the research. Their general traits are shown in Table 1, and geographical position in Figure 1.

In the autumn of 2013, the seeds were collected from all eight populations. After the analyses of quality and health had been conducted in a laboratory, in the spring of 2014 a nursery test was established in the nursery of the Institute of Forestry. A hotbed with dimensions of $24 \mathrm{~m} \times 1 \mathrm{~m}$ has been divided into 24 equal fields measuring $1 \mathrm{~m} \times 1 \mathrm{~m}$. The trial had been set in three replications (all eight populations were represented in one replication). In each field, 100 seeds had been planted. After sowing, the seeds were covered with a substrate layer of $2 \mathrm{~cm}$ thickness. The mechanical weeding, hoeing, and watering were performed during the first and second vegetation periods.

At the end of the growing seasons of 2014 and 2015, at the $1+0$ and $2+0$ age of seedlings, measuring of height and root collar diameter was carried out. The height was measured by a ruler with an accuracy of $0.1 \mathrm{~cm}$, and root collar diameter by a vernier calliper with an accuracy of 0.1 $\mathrm{mm}$.

The measured morphometric traits of seedlings were processed in the statistical software package Statistica 7.0 (StatSoft Inc. 2004). Basic statistical parameters were calculated for each of the measured traits. The significance of the differences between the mean values of the analysed parameters was verified by one-way analysis of variance (One-Way ANOVA), where the analysed factor was a population.

The additional testing using Fisher's LSD test was carried out in order to determine populations form homogeneity groups. Pearson's correlation coefficient was conducted using the R function in the Hmisc package by Harrell et al. (2019) to determine significant correlations between the analyzed traits and the climate variables of the original habitats of the populations. The inputs for the correlation coefficient were the arithmetic means of the populations for the analyzed morphological traits and different climatic variables connected with their original stands. Interpolated climate data for the reference period 1961-2009 generated by the ClimateEU software (Marchi et al. 2020) were used to characterize the long-term climatic conditions of the original stands. A detailed explanation of the assessment of all available climate variables provided by the ClimateEU software can be found in Wang et al. (2012). For the

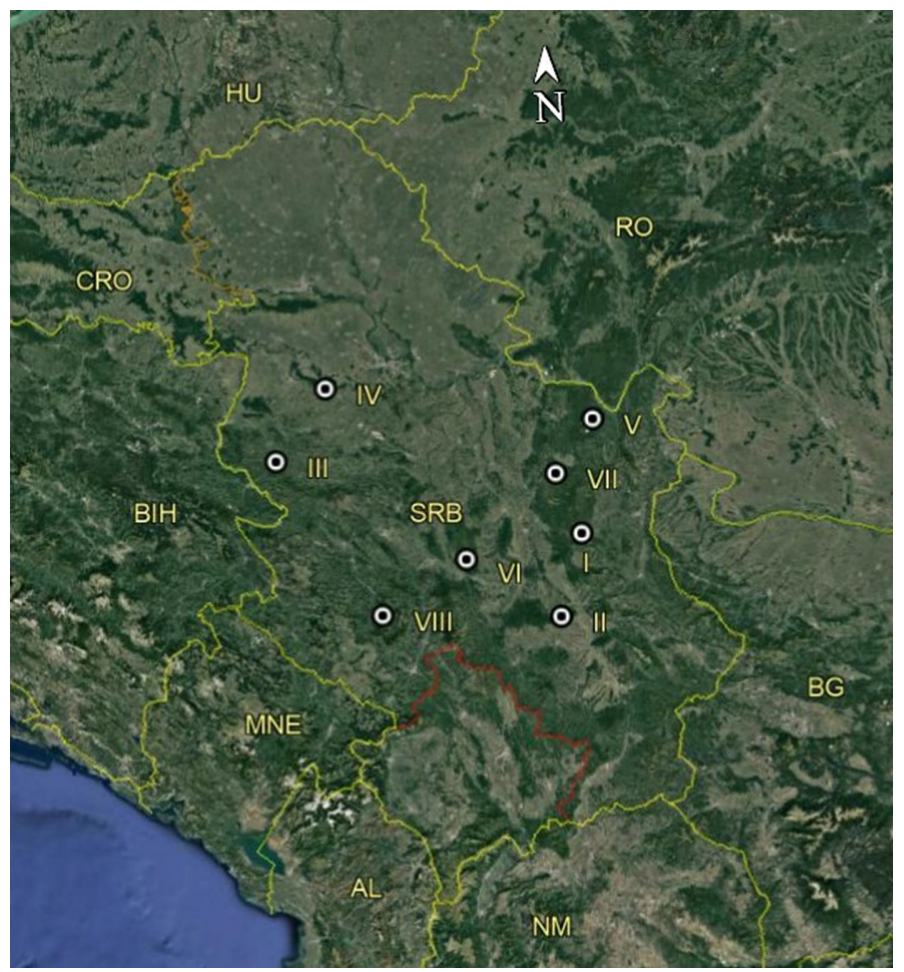

Figure 1. Geographical location of analysed beech populations. 
Table 1. General traits of analysed beech populations.

\begin{tabular}{|c|c|c|c|c|c|c|c|c|}
\hline $\begin{array}{l}\text { Population } \\
\text { Mark }\end{array}$ & Population & Exposition & $\begin{array}{l}\text { Elevation } \\
\text { (m) }\end{array}$ & $\begin{array}{l}\text { Latitude } \\
\text { WGS84 }\end{array}$ & $\begin{array}{l}\text { Longitude } \\
\text { WGS84 }\end{array}$ & Forest association & $\begin{array}{c}\text { Annual mean } \\
\text { temperature } \\
\left({ }^{\circ} \mathrm{C}\right)\end{array}$ & $\begin{array}{c}\text { Annual } \\
\text { precipitation } \\
(\mathrm{mm})\end{array}$ \\
\hline 1 & Dubašnica & northwest & 870 & 44.100629 & 21.888005 & $\begin{array}{c}\text { Fagenion moesiaceae } \\
\text { montanum }\end{array}$ & 7.3 & 790 \\
\hline II & Jastrebac & northeast & 790 & 43.556586 & 21.761478 & $\begin{array}{c}\text { Fagenion moesiaceae } \\
\text { montanum }\end{array}$ & 7.9 & 666 \\
\hline III & Boranja & southeast & 650 & 44.389965 & 19.289810 & $\begin{array}{l}\text { Fagenion moesiaceae } \\
\text { submontanum }\end{array}$ & 8.8 & 875 \\
\hline IV & Fruška Gora & $\begin{array}{c}\text { north, } \\
\text { northeast }\end{array}$ & 400 & 45.141938 & 19.622889 & Qerceto-Fagetyum & 9.5 & 699 \\
\hline V & Mali Pek & northeast & 650 & 44.458935 & 21.978872 & $\begin{array}{l}\text { Fagenion moesiaceae } \\
\text { submontanum }\end{array}$ & 8.3 & 764 \\
\hline $\mathrm{VI}$ & Goč & $\begin{array}{l}\text { north, } \\
\text { northeast }\end{array}$ & 900 & 43.56751 & 20.854722 & $\begin{array}{l}\text { Abieti-Fagetum } \\
\text { serpentinicum }\end{array}$ & 7.6 & 833 \\
\hline VII & Beljanica & $\begin{array}{l}\text { north, } \\
\text { northeast }\end{array}$ & 700 & 44.070153 & 21.757080 & $\begin{array}{c}\text { Fagenion moesiaceae } \\
\text { montanum }\end{array}$ & 8.3 & 782 \\
\hline VIII & Javor & northwest & 1300 & 43.455000 & 20.018890 & $\begin{array}{c}\text { Fagenion moesiaceae } \\
\text { montanum }\end{array}$ & 5.9 & 1007 \\
\hline
\end{tabular}

purpose of the populations' grouping based on the analysed morphometric traits of seedlings, a cluster analysis was applied using a single linkage method (single linkage Euclidean distance).

\section{RESULTS AND DISCUSSION}

The mean values of the seedlings' root collar diameter by population are presented in Figure 2. At the end of the first growing season, the Boranja population seedlings achieved the highest mean value of root collar diameter $(2.86 \mathrm{~mm})$, and seedlings of the Javor population the lowest $(2.39 \mathrm{~mm})$. During the second growing season diameter increment trend changed, so at the end of the growing season the Goč population had the highest mean value of the root collar diameter (3.99 $\mathrm{mm}$ ), while the lowest mean value of this parameter was recorded in the Mali Pek population (3.22 mm). The highest variability of the studied trait in one-year-old seedlings was found in the Beljanica population (20.9\%) and in two-year-old seedlings in the Mali Pek population (23.2\%). The lowest variability at the level of one-year-old seedlings was found in the Javor population (13.2\%), and at the level of two-year-old seedlings the lowest variability of the root collar diameter was found in the Dubašnica population (13.5\%).

The differences between populations for the root collar diameter trait were statistically highly significant both in oneand two-year-old seedlings (Table 2).

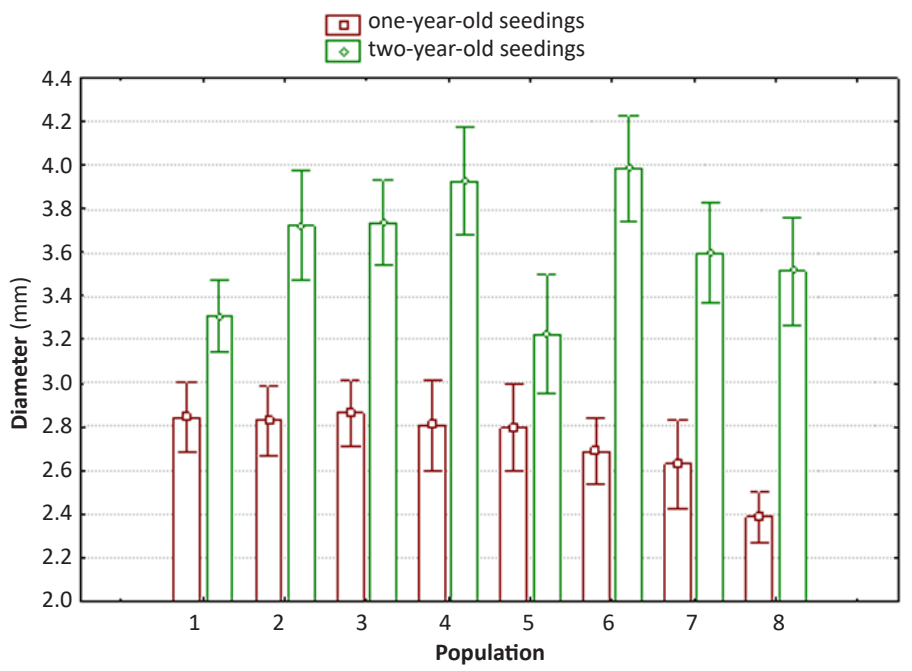

Figure 2. Boxplot of root collar diameter data per provenance. 


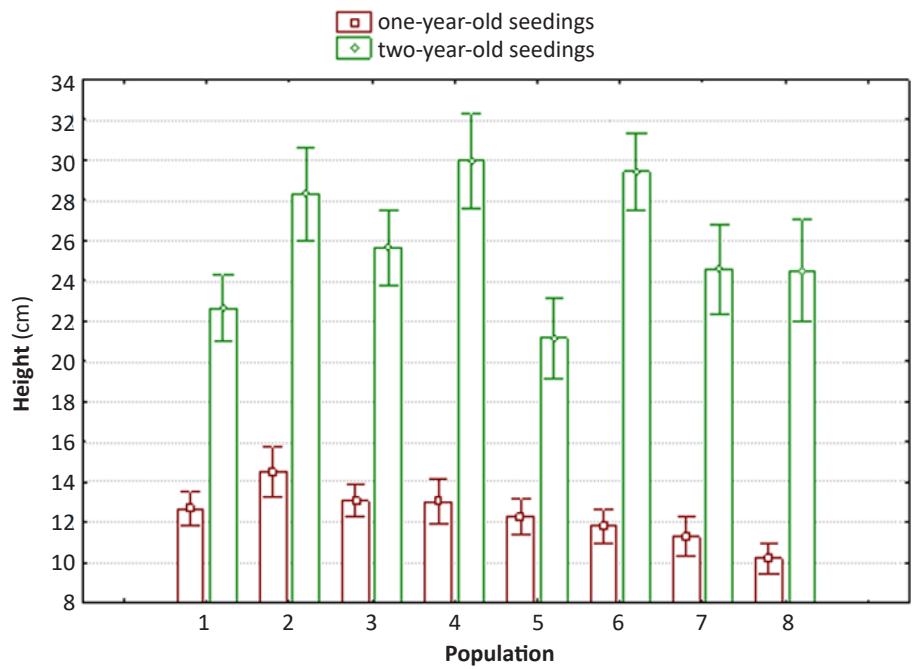

Figure 3. Boxplot of height increment data per provenance.

Mean values of the seedlings' height at the age of $1+0$ and $2+0$ by populations are presented in Figure 3 . The highest mean value of one-year-old seedlings' height was measured in the Jastrebac population $(14.5 \mathrm{~cm})$, and the lowest in the Javor population $(10.2 \mathrm{~cm})$. At the end of the second growing season the highest mean value of height was measured in the seedlings of the Fruška Gora population (30 $\mathrm{cm}$ ) and the lowest mean value in the seedlings of the Mali Pek population $(21.2 \mathrm{~cm})$. Regarding the height of one-yearold seedlings, the highest variability was found in the Fruška Gora and Beljanica populations (23.2\%) and the lowest in the Boranja population (16.4\%). The highest variability

Table 2. The analysis of variance (ANOVA) for the traits root collar diameter (d) and height ( $h$ ) of one-year-old and two-yearold seedlings (the same letters associate populations with no statistically significant differences).

\begin{tabular}{ccccc}
\hline & \multicolumn{4}{c}{ Trait } \\
\cline { 2 - 5 } Population & \multicolumn{2}{c}{$\begin{array}{c}\text { One-year-old } \\
\text { seedlings }\end{array}$} & \multicolumn{2}{c}{$\begin{array}{c}\text { Two-year-old } \\
\text { seedlings }\end{array}$} \\
\cline { 2 - 5 } & $\begin{array}{c}\mathbf{d} \\
(\mathrm{cm})\end{array}$ & $\begin{array}{c}\mathrm{h} \\
(\mathrm{cm})\end{array}$ & $\begin{array}{c}\mathrm{d} \\
(\mathrm{cm})\end{array}$ & $\begin{array}{c}\mathrm{h} \\
(\mathrm{cm})\end{array}$ \\
\hline I & $2.84^{\mathrm{bc}}$ & $12.3^{\mathrm{c}}$ & $3.31^{\mathrm{ab}}$ & $22.6^{\mathrm{ab}}$ \\
II & $2.83^{\mathrm{bc}}$ & $14.5^{\mathrm{d}}$ & $3.72^{\mathrm{bc}}$ & $28.3^{\mathrm{cd}}$ \\
III & $2.86^{\mathrm{c}}$ & $13.1^{\mathrm{c}}$ & $3.74^{\mathrm{bc}}$ & $25.7^{\mathrm{bc}}$ \\
IV & $2.81^{\mathrm{bc}}$ & $13.0^{\mathrm{c}}$ & $3.93^{\mathrm{c}}$ & $30.0^{\mathrm{d}}$ \\
V & $2.80^{\mathrm{bc}}$ & $12.3^{\mathrm{bc}}$ & $3.22^{\mathrm{a}}$ & $21.2^{\mathrm{a}}$ \\
VI & $2.70^{\mathrm{bc}}$ & $11.8^{\mathrm{bc}}$ & $3.99^{\mathrm{c}}$ & $29.4^{\mathrm{d}}$ \\
VII & $2.63^{\mathrm{b}}$ & $11.3^{\mathrm{ab}}$ & $3.59^{\mathrm{bc}}$ & $24.6^{\mathrm{bc}}$ \\
VIII & $2.39^{\mathrm{a}}$ & $10.2^{\mathrm{a}}$ & $3.51^{\mathrm{ab}}$ & $24.5^{\mathrm{bc}}$ \\
P-value & 0.0008 & 0.0000 & 0.0000 & 0.0000 \\
\hline
\end{tabular}

in height of two-year-old seedlings was determined in the Javor population (28.8\%) and the lowest in the Goc population (17.8\%).

Based on the obtained results of the analysis of variance (ANOVA), it can be concluded that statistically significant differences were found between the studied populations for the analysed morphological traits of seedlings (Table 2). Based on the results of the LSD test, no clear formation of homogeneity groups can be observed. When observing the two-year-old seedlings' traits, the Javor population stands out with the lowest values, while the populations of Dubašnica, Jastrebac and Fruška Gora form a homogeneity group with the highest values. On the other hand, the Mali Pek population stands out with the lowest measured values, while the populations of Fruška Gora and Goč form a homogeneity group that shows the highest values of the measured traits.

In order to determine the pattern in the variations of the studied traits between populations, we conducted the Pearson correlation coefficient between the average values of the populations and the climate and geographical variables of their origin stands (Table 3). Statistically significant correlations were determined in the morphological traits of one-year-old seedlings. The root collar diameter was significantly positively correlated with mean annual temperature (MAT) and negatively correlated with elevation (Elev), mean annual precipitation (MAP), mean summer precipitation (MSP), sum of degree-days $\angle 0^{\circ} \mathrm{C}$ (DD_0), sum of degree-days $<18^{\circ} \mathrm{C}$ (DD_18), and precipitation as snow (PAS). Seedling height was negatively correlated with mean annual precipitation (MAP), mean summer precipitation (MSP), summer heat-to-moisture index (SHM), and climate moisture deficit (CMD).

The estimation of proximity, i.e., a distance of the studied populations based on measured morphometric seedling traits was conducted by applying cluster analysis. 


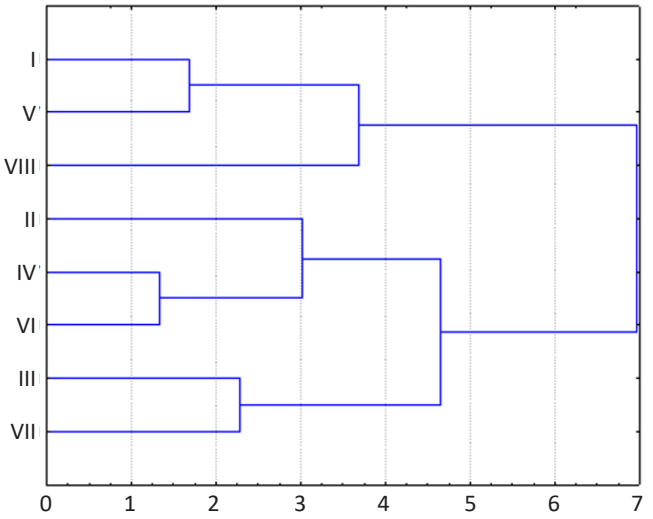

Figure 4. Cluster analysis for measured traits of seedlings.

The populations of Fruška Gora (IV) and Goč (VI), i.e., of Dubašnica (I) and Mali Pek (V) are at the smallest distance (Chart 1). There is no geographic connection or differentiation of the studied populations.

The quantitative traits of beech seedlings have not been extensively studied in Serbia to date. Reasons for the low interest lie primarily in the fact that beech stands are primarily restored naturally. However, in the last few decades, the problem of natural renewal has been more expressed and the necessity of assisted renewal has arisen. This is especially pronounced in the last few years, when natural stands decline over large areas due to changed environmental conditions. In order to ensure the survival of beech in its natural habitats, it is necessary to provide quality reproductive material that will be able to withstand increasing climate change and preserve genetic diversity in the future.

The obtained results indicate the existence of a significant level of variability of beech populations in Serbia, given the studied seedling traits (Figure 2, 3). The height of two-year-old seedlings was the most variable trait, while the one-year-old seedlings' root collar diameter proved to be the least variable. Observing the mean values of one-yearold seedlings' individual traits at the level of populations, the Jastrebac population stands out with the highest values and the Javor population with the lowest. When observing traits of the two-year-old seedlings, the populations of Goc and Fruška Gora stand out with the highest values, while the population of Mali Pek stands out with the lowest values of individual traits.

The results of the analysis of variance showed statistically significant differences caused by the population effect (Table 2). This indicates genetically determined differences of the quantitative traits of seedlings between the analysed populations.

The correlation analysis of average values of seedling traits with climate and geographical variables of populations, indicated the possibility of using seedlings' morphological traits as a tool to investigate the population
Table 3. Statistical significance ( $p$-values) of Pearson's correlation coefficients between analyzed trait population means and climate (geographic) variables of their stands of origin $\left({ }^{*}\right.$ - statistically significant correlations, $\left.\mathrm{p}<0.05\right)$.

\begin{tabular}{ccccc}
\hline & One-year-old seedlings & \multicolumn{2}{l}{ Two-year-old seedlings } \\
\cline { 2 - 5 } & $\mathbf{d}$ & $\mathbf{h}$ & $\mathbf{d}$ & $\mathbf{h}$ \\
\hline Lat & 0.231 & 0.646 & 0.968 & 0.980 \\
Long & 0.803 & 0.859 & 0.135 & 0.236 \\
Elev & $0.032^{*}$ & 0.129 & 0.580 & 0.580 \\
MAT & $0.047^{*}$ & 0.145 & 0.401 & 0.448 \\
MWMT & $0.030^{*}$ & 0.140 & 0.817 & 0.719 \\
MCMT & $0.016^{*}$ & 0.121 & 0.936 & 0.885 \\
TD & 0.104 & 0.222 & 0.657 & 0.508 \\
MAP & $0.048^{*}$ & $0.025 *$ & 0.749 & 0.485 \\
MSP & 0.180 & $0.041 *$ & 0.558 & 0.262 \\
AHM & 0.052 & 0.059 & 0.802 & 0.552 \\
SHM & 0.080 & $0.042^{*}$ & 0.585 & 0.335 \\
DD_0 & $0.009^{*}$ & 0.074 & 0.645 & 0.607 \\
DD5 & $0.025^{*}$ & 0.122 & 0.779 & 0.676 \\
DD_18 & $0.016^{*}$ & 0.097 & 0.732 & 0.651 \\
DD18 & 0.085 & 0.227 & 0.852 & 0.711 \\
NFFD & $0.033^{*}$ & 0.223 & 0.981 & 0.973 \\
bFFP & 0.083 & 0.372 & 0.815 & 0.871 \\
eFFP & 0.082 & 0.357 & 0.682 & 0.745 \\
FFP & 0.081 & 0.363 & 0.760 & 0.819 \\
PAS & $0.007^{*}$ & 0.058 & 0.757 & 0.682 \\
CMD & 0.146 & $0.034 *$ & 0.387 & 0.165 \\
\hline L & & & & \\
\hline
\end{tabular}

Lat - latitude; Long - longitude; Elev - elevation; MAT - mean annual temperature; MWMT - mean July temperature; MCMT - mean January temperature; TD - continentality index; MAP - mean annual precipitation; MSP - mean summer precipitation; AHM - annual heatto moisture index; SHM - summer heat-to-moisture index; DD_0 - sum of degree-days $<0^{\circ} \mathrm{C}$; DD5 - sum of degree-days $>5^{\circ} \mathrm{C}$; DD_18- sum of degree-days $<18^{\circ} \mathrm{C}$; DD18 - sum of degree-days $>18^{\circ} \mathrm{C}$; NFFD - number of frost free days; bFFP - beginning of frost free period; eFFP - end of frost free period; PAS - precipitation as snow; CMD - climate moisture deficit.

variability pattern (Table 3). This research indicates an ecotypic population variability pattern, namely, the results of the correlation analysis discovered a pattern of clinal variability between populations associated with elevation and the correlated climatic variables of the original habitats. The established pattern indicates the genetic variability of populations, i.e. the possibility that populations were genetically differentiated through natural selection.

Several authors who conducted researches on some adaptive traits determined a clinal pattern of beech genetic variability (in the direction northwest-southeast) (von Wuehlisch et al. 1995, Nielsen and Jorgensen 2003, Gömöry et al. 2007, Ivanković et al. 2011). In other studies, an ecotypic (random) pattern of interpopulation variability 
was determined (Comps et al. 1991, Paule 1995, Gömöry et al. 1998, Chmura and Rozkowski 2002, Jazbec et al. 2007, Ivanković et al. 2008, Gavranović et al. 2018, Bogunović et al. 2020). In our research, the results are more in line with the ecotypic variability pattern, although for the conclusion on ecotypic genetic variability it is necessary to conduct additional research that would combine the results of the analysis of progeny tests with the data on ecological parameters of mother stands from which the analysed populations originate. The fact is that the progeny trial has been established in the seedling nursery where the growth conditions are optimal, namely, better than in their parent stands. Màtyàs et al. (2009) showed that genetic differences in height growth among populations were better detected in more stressful site conditions, i.e., they were more difficult to detect in favourable site conditions.

The importance of the proper choice of the reproductive material, along with the proper breeding interventions, is considered to be the main precondition for achieving the maximum benefit of forestry production (Kingswell 1998, Coello et al. 2013). However, the possibility of genetic differentiation of populations dictates the need for caution when choosing reproductive material for assisted reproduction. We believe that the results of our research can recommend the selection of beech seed stands in Serbia with regard to elevation.

\section{CONCLUSIONS}

The results confirming the existence of genetic differences among the studied populations were obtained by analysing the growth of beech seedlings during two growing seasons in the nursery test. The differences in height and diameter growth determined among populations indicate the ecotypic nature of beech genetic variability. The Javor population, which, according to the measured parameters, at the end of the first growing season lagged behind, showed significantly higher increment compared to other populations in the second growing season. The Goč and Fruška Gora populations stand out with the highest values of measurement parameters, while in the Dubašnica and Mali Pek populations the lowest values were measured for two-year-old seedlings. Bearing in mind the optimal conditions for seedling growth and development in the seedling nursery, the more distinct differences can be expected after moving seedlings to the field where more stressful environmental conditions occur. The determined variability of morphometric traits can be an indicator for further development of selected populations' seedlings. The conducted researches are important for the improvement of production technology and they recommend the transfer and use of beech forest reproductive material.

\section{Author Contributions}

VP and AL conceived and designed the research, VP and $\mathrm{AL}$ carried out the field measurements, VP conceptualization, methodology, investigation, performed statistical analyses, data curation, visualization results, LR secured the research funding, supervised the research and helped to draft the manuscript, VP and $\mathrm{AL}$ writing and reviewing the final version of the manuscript, approved the submitted version.

\section{Funding}

The research is financed by the Ministry of Education, Science and Technological Development of the Republic of Serbia, Project TR 31070 "The development of technological procedures in forestry with a view to an optimum forest cover realization" (2011-2020).

\section{Conflicts of Interest}

The authors declare no conflict of interest.

\section{REFERENCES}

Bogunović S, Bogdan S, Lanšćak $M$, Ćelepirović $N$, Ivanković M, 2020. Use of a Common Garden Experiment in Selecting Adapted Beech Provenances for Artificial Stand Restoration. South-east Eur for 11(1): 1-10. https://doi.org/10.15177/ seefor.20-07.

Brus R, 2010. Growing evidence for the existence of glacial refugia of European beech (Fagus sylvatica L.) in the southeastern Alps and north-western Dinaric Alps. Period Biol 112(3): 239-246.

Chmura Dj, Rozkowski R, 2002. Variability of beech provenances in spring and autumn phenology. Silvae Genet 51(2-3): 123127.

Coello J, Becquey J, Gonin P, Ortisset Jean P, Desombre V, Baiges $T$, Piqué $M, 2013$. Ecology and silviculture of the main valuable broadleaved species in the Pyrenean area and neighbouring regions. Government of Catalonia, Ministry of Agriculture, Livestock, Fisheries, Food and Natural Environment - Catalan Forest Ownership Centre, Santa Perpètua de Mogoda,Spain, pp. 13-20.

Comps B, Thiebau B, Šugar I, Trinajstić I, Plazibat M, 1991. Genetic variation of the Croatian beech stands (Fagus sylvatica L.): spatial differentiation in connection with the environment. Ann For Sci 48(1): 15-28. https://doi.org/10.1051/ forest:19910102.

Gavranović A, Bogdan S, Lanšćak M, Čehulić I, Ivanković M, 2018. Seed Yield and Morphological Variations of Beechnuts in Four European Beech (Fagus sylvatica L.) Populations in Croatia. South-east Eur for 9(1): 17-27. https://doi.org/10.15177/ seefor.18-06.

Gračan J, 2003. Achievements in breeding common beech in Croatia. In: Matić S (ed) Common beech in Croatia. Akademija šumarskih znanosti, Zagreb, Croatia.

Gömöry D, Hynek V, Paule L, 1998. Delineation of seed zones for European beech (Fagus sylvatica L.) in the Czech Republic based on isozyme gene markers. Ann For Sci 55(4): 425-436. https://doi.org/10.1051/forest:19980403.

Gömöry D, 1999. Genetic differentiation and phylogeny of beech on the Balkan peninsula. J Evolution Biol 12(4): 746-754. https://doi.org/10.1046/j.1420-9101.1999.00076.x. 
Gömöry D, Paule L, Vysny J, 2007. Patterns of allozyme variation in western Eurasian Fagus. Bot J Linn Soc 154(2): 165-174. https://doi.org/10.1111/j.1095-8339.2007.00666.x.

Harrell FE Jr et al., 2019. Hmisc: Harrell Miscellaneous. R package version 4.3-0. https://CRAN.R-project.org/package=Hmisc.

Hazler K, Comps B, Šugar I, Melovski L, Tashev A, Gračan J, 1997. Genetic structure of Fagus sylvatica L. populations in Southern Europe. Silvae Genet 46: 229-236.

Ivanković M, Popović M, Katičić I, Von Wuehlisch G, Bogdan S, 2011. Quantitative genetic variation of European beech (Fagus sylvatica L.) provenances from the southeastern Europe. Sumar List 135(13): 25-37.

Jazbec A, Šegotić K, Ivanković M, Marjanović H, Perić S, 2007. Ranking of European beech provenances in Croatia using statistical analysis and analytical hierarchy process. Forestry 80(2): 151-162. https://doi.org/10.1093/forestry/cpm007.

Kajba D, 2003. Intrapopulation and interpopulation variability of common beech. In: Matić S (ed) Common beech in Croatia. Akademija šumarskih znanosti, Zagreb, Croatia.

Kingswell G, 1998. Tree Biotehnology: Toward the Milenium, Davey MR, Alderson PG, Lowe KC, Power JB (eds). School of Biological Sciencies, University of Nottingham, UK, pp. 23-29.

Màtyàs C, Božič G, Gömöry D, Ivanković M, Rasztovits E, 2009. Transfer analysis of provenance trials reveals macroclimatic adaptedness of European beech (Fagus sylvatica L.). Acta Silv Lign Hung 5: 47-62.

Marchi M, Castellanos-Acuna D, Hamann A, Wang T, Ray D, Menzel A, 2020. ClimateEU, scale-free climate normals, historical time series, and future projections for Europe. Scientific Data 7: 428. https://doi.org/10.1038/s41597-020-00763-0.
Nielsen CHN, Jorgensen FV, 2003. Phenology and diameter increment in seedlings of European beech (Fagus sylvatica L.) as affected by different soil water contents: variation between and within provenances. Forest Ecol Manag 174(1-3): 233249. https://doi.org/10.1016/S0378-1127(02)00042-7.

Paule L, 1995. Gene conservation in European beech (Fagus sylvatica L.). Forest Genetics 2(3): 161-170.

Pšidová E, Ditmarová L, Jamnická G, Kurjak D, Majerová J, Czajkowski T, Bolte A, 2015. Photosynthetic response of beech seedlings of different origin to water deficit. Photosynthetica 53(2): 187-194. https://doi.org/10.1007/s11099-015-0101-x.

StatSoft Inc., 2004. Statistica (version 7) [Data Analysis Software System].

Vidaković M, Krstinić A, 1985. Genetika i oplemenjivanje šumskog drveća [Genetics and breeding of forest trees]. University of Zagreb, Faculty of Forestry, Zagreb, Croatia, pp. 436-441.

Von Wuehlisch G, Krusche D, Muhs $\mathrm{Hj}$, 1995. Variation in temperature sum requirement for flushing of beech provenances. Silvae Genet 44(5-6): 343-346

Šijačić Nikolić M, Ivetić V, Knežević R, Milovanović J, 2007. Analiza svojstava semena i klijavaca različitih provenijencija brdske bukve [Analysis of seed and seedling traits of different provenances of beech]. Acta herbologica 16(1): 15-27.

Wang T, Hamann A, Spittlehouse DI, Murdock TQ, 2012. ClimateWNA - Highresolution spatial climate data for western North America. J Appl Meteorol Clim 51(1): 16-29. https://doi. org/10.1175/JAMC-D-11-043.1. 